\title{
Refusal Strategies in Offers and Directives: An Overview of Selected Texts from Radio Drama Episodes
}

\author{
Acheoah John Emike \\ PhD- Department of European Languages- Federal University- Birnin-kebbi- Nigeria. \\ actualemike@gmail.com
}

\begin{abstract}
This study attempts an overview of different refusal strategies used by characters in the drama genre, and by extension, humans in everyday communication. Although the study is neither strictly a stylistic nor pragmatic analysis of texts, it is an investigation of the stylo-pragmatic components that make the refusals potent and acceptable to the performer of the offer or directive. The drama episodes analyzed in this study are acted in English. In the performance of the speech act of refusing, participants of discourse have to be appropriate and skillful. Indeed, refusing in an appropriate way indexes a participant's pragmatic competence. When an offer or directive is made, whether the refuser is pleased with it or not, he/she employs a polite refusal strategy which sometimes involves making deceitful propositions. On the whole, refusal strategies in the drama genre and include expression of excuse, reason, willingness, self-defense, explanation, topic shift, alternative and dissuading one's interlocutor.
\end{abstract}

Keywords: Refusal strategy, directive, offer, drama, stylistics, pragmatics

\section{Introduction}

There is no limit to which participants of discourse can explore or deploy language. This is because meaning is a continuum. Various factors govern participants' choice of language. Coherence is crucial to conversation because it generates expected perlocutionary acts. Utterances in human interaction are immersed in shared knowledge and such utterances produce felicitous results to the interaction; because expressions have referents in the world, language has to be skillfully selected towards effective communication of illocutionary goals. Indeed, this process may involve the violation of linguistic norms. Language philosophers acknowledge that the goals of pragmatics is to process language for smooth communication. Thus, the functional dimension of language operates when language is representational. Language cannot be detached from its social context if the communication of meaning is language users' goal.

When non-native speakers of English perform the speech act of refusal effectively, they essentially demonstrate communicative competence in the language. Al-Kahtani (2005) notes that "second language (L2) learners' pragmatic competence has long been the subject of heated discussion in language teaching. Moreover, refusing can be a very challenging task to perform even in one's native language (L1)." This paper examines the linguistic structure of the speech act of refusing within and beyond the drama genre. As used in this paper, the following expressions should be noted:

- Offerer (the person making an offer);

- Offeree (the person receiving an offer);

- Director (the person giving a directive);

- Directee (the person refusing a directive). 


\section{Purpose of the Study}

This paper attempts to find out:

- Common refusal strategies in the drama genre;

- The pragmatic nuances that determine refusal strategies in discourse;

- How offerees and directees use indirect refusal strategy in different contexts.

\section{Literature Review}

In this section, the study examines the literature of refusal strategy, stylistics and pragmatics

\subsection{The Speech Act of Refusal}

Studies on refusal strategies focus on different phenomena, and produce similar or different results, irrespective of their methodological differences. This view corroborates Al-Kahtani (2005) a cross-cultural study of refusal strategy. Scholars believe that refusal strategies in a foreign language have to be consciously studied to avoid breakdown in cross-cultural communication. Seyyed Hatan Tamimi Sa'd and Zohr Qadermaz (2014) submit that "certain patterns of refusing are followed by both EFL and non-English learners, which might be indicative of the formulaic nature of the speech act of refusal. This conclusion might be tenable on the grounds that other speech acts, such as complimenting, have been found to be highly formulaic in nature... a finding that can turn to be generalizable to refusal behaviour as well..."

Fairclough (1996) shows that language use is indeed, a social phenomenon.

Elucidating the term refusal, (Xin Li and Jiequiong Sun, 2018, p. 68) cites Miles, (1994, p. 279) who posits that refusal is "asset of measures the communicator utilizes for the sake of smooth communication or adaptation to the social norms in which he lives." According to Xin Li and Jiequiong Sun, ibid., p. 68) the refusal speech act "can be performed either strategically or nonstrategically... Strategic refusals are those which cater to the interpersonal needs of communicators. They often involved different types of politeness strategies (also known as refusing strategies) for the purpose of softening the illocutionary force embedded in refusals or redressing face-loss of the interlocutor. On the other hand, non-strategic refusals usually cater to the refuser's own personal or actionable goal and the result of such communication often leads to international conflict or the deterioration of the relationship between the interlocutors". In addition, Chen, Ye, and Zhang (1995) cited in Xin LI Jieqiong, (2018, p. 70) submit that "there are two main types of refusals: substantive refusals and ritual refusals. The former means those in which a refusal is intended while the latter means a polite act indicating the refuser's concern for the person doing the offering or inviting. In other words, in substantive refusals the speaker says no and means no while what they called "ritual refusals" is characteristic of Chinese interaction in which speakers may say no to initiations such as offers and invitations when in fact they are willing to accept." Numerous contemporary studies abound on the speech act of refusal. For example, Seyyed Hatam Tamimi Sa'ad and Zohre Qadermazi, 2014, p. 125) reports that "research into L2 production of speech acts in general and refusals in particular has been increasingly rigorous..."

\subsection{Stylistics}

Stylistics is simply the study of style - the way language is used in a given context, by a given person, for a given purpose. Leech and Short (1981) posit that "style can be applied to both spoken and written, both literary and non-literary varieties of language, but by tradition, it is particularly associated with written literary texts." Stylistic analysis is rigorous and a systematic. For 
a clear understanding of this field of linguistics, see Leech and Michael (1981), Fakuade (1989) and Lawal (1999).

\subsection{Pragmatics}

Pragmatics is the study of how context determines the use and interpretation of language. Concepts that explain pragmatics include speech act, presupposition, implicature, inference, shared knowledge, etc. See Austin (1962), Searle (1969), Grice (1975), Bach and Harnish (1979) and Mey (2001) for insights on pragmatics.

\section{Methodology}

This study examines twelve data in two groups of six. The first six are Offers while the following six are Directives. The data are adjacency pairs presented and analyzed in prefered tabular form. After presenting the situational context of the offer or directive, the refusal articulated by the offeree or directee is presented before the analysis which reveals strategy typology, style and the pragmatics.

\subsection{Subjects/Participants}

The participants of the discourses are actors and actresses (major and minor characters) in the drama episodes.

\subsection{Instrument}

The selected texts (offers 1-6 and directives 1-6) are generated via tape recording. They are extracted using certain parameters: status of the participants, situational context and indirect-act potentials.

\section{Presentation and Analysis of Data}

This section presents and analyzes the data as stated above:

\begin{tabular}{|l|l|}
\hline $\begin{array}{l}\text { Offer: } \\
\text { Have some wine, please. }\end{array}$ & $\begin{array}{l}\text { Refusal: } \\
\text { Exactly the type I drank a few minutes ago. I am not used to } \\
\text { drinking much of it. } \\
\text { Situational Context: The encoder receives a visitor in his } \\
\text { residence, and attempts to entertain the visitor. } \\
\text { Strategy: excuse; reason; explanation } \\
\text { Style: The decoder aligns with his interlocutor's practice and } \\
\text { gives an excuse. } \\
\text { The Pragmatics: Even though the visitor has never taken that } \\
\text { type of wine before, his strategy appeases the encoder because } \\
\text { it gives credibility to both the offerer and the offeree. When } \\
\text { people consume the same products, a sort of bond is } \\
\text { established. In this text, the participants' world knowledge } \\
\text { evokes bond. So long as the encoder is aware that excess wine } \\
\text { intoxicates, his interlocutor successfully escapes the offer by } \\
\text { stating that just a few minutes before the conversation, he took } \\
\text { much wine. }\end{array}$ \\
\hline Can I give you a lift? & $\begin{array}{l}\text { Oh! Walking a short distance keeps me fit. } \\
\text { Situational Context: A man drives a car out of his compound, } \\
\text { meets his neighbour, and attempts to give his neighbour a lift. } \\
\text { Strategy: reason; explanation } \\
\text { Style: The "offeree" adds an excuse to an exclamation. The } \\
\text { exclamation serves the purpose of establishing a positive } \\
\text { feeling towards the offer. } \\
\text { The Pragmatics: The offeree's utterance is persuasive }\end{array}$ \\
\hline
\end{tabular}




\begin{tabular}{|c|c|}
\hline & $\begin{array}{l}\text { because his interlocutor is also aware of the importance of } \\
\text { exercise to the body (shared knowledge). The exclamation is a } \\
\text { preparatory locutionary strategy; in the situation of the } \\
\text { utterance, the encoder of Ho! is certainly not frowning but } \\
\text { laughing. }\end{array}$ \\
\hline 3. Consider these products for your health. & $\begin{array}{l}\text { Wao! I have heard so much about their efficacy. The problem } \\
\text { is lack of money. } \\
\text { Situational Context: A sales representative of a } \\
\text { pharmaceutical company meets a lady on a street and tries to } \\
\text { advertise and sale the products to her. } \\
\text { Strategy: expression of willingness } \\
\text { Style: The offeree makes positive remarks about the products } \\
\text { and concludes with an excuse. } \\
\text { The Pragmatics: The offeree's utterance is enough feedback, } \\
\text { not just to the sales representative, but also to the company. } \\
\text { Market acceptance of commercial products is of importance to } \\
\text { manufacturers. Even if the offer is rejected, it can be inferred } \\
\text { that the offeree believed the excuse. }\end{array}$ \\
\hline 4. Here is meal. Help yourself. & $\begin{array}{l}\text { I am sure you'll want me to be a responsible husband, having } \\
\text { space in my belly for a wife's dinner. } \\
\text { Situational Context: A man visits his friend during a } \\
\text { weekend. The friend's wife prepared meal and encodes the } \\
\text { offer. } \\
\text { Strategy: reason; excuse; self-defence } \\
\text { Style: The offeree engages the offerer in reasoning by making } \\
\text { a logical conclusion. } \\
\text { The Pragmatics: Hinging on the contextual structure of the } \\
\text { offer (a domestic setting) as well as societal norm, the offeree } \\
\text { perfects his excuse. Both the offerer and the offeree believe } \\
\text { that marriage is a sensitive union that thrives when the rules } \\
\text { are carefully and consciously obeyed. }\end{array}$ \\
\hline $\begin{array}{l}\text { 5. These gifts are for our customers. Why not pick } \\
\text { some? }\end{array}$ & $\begin{array}{l}\text { Please, do not spoil me with your continuous gifts. } \\
\text { Situational Context: The participants are in a bank. Assorted } \\
\text { gifts were on a table. The encoder of the offer is staff of the } \\
\text { bank. } \\
\text { Strategy: dissuading } \\
\text { Style: The offeree uses contextual recall to encode an implied } \\
\text { gratitude. } \\
\text { The Pragmatics: The participants have shared knowledge of } \\
\text { related antecedents involving previous offers; the antecedents } \\
\text { make the expressions spoil and continuous gifts cohere in the } \\
\text { text. }\end{array}$ \\
\hline 6. I'll hold your bag while you climb the tree. & $\begin{array}{l}\text { Unless I climb with it, I am not yet a professional climber. } \\
\text { Situational Context: After school hours, a teacher requests } \\
\text { her pupil to climb a mango tree to pluck some mangoes for } \\
\text { her. } \\
\text { Strategy: reason; excuse; explanation; self-defense } \\
\text { Style: The offeree uses professional ethics to justify his } \\
\text { refusal. However, the utterance is mainly an excuse. } \\
\text { The Pragmatics: The offerer is not comfortable with the offer } \\
\text { because of the offeree's status. The offeree thinks saying No to } \\
\text { the offer would be rude. }\end{array}$ \\
\hline $\begin{array}{l}\text { Directive: } \\
\text { 1. Complete the memo before my arrival. }\end{array}$ & $\begin{array}{l}\text { Refusal: } \\
\text { How I wish good memos are easily written. } \\
\text { Situational Context: The speaker is a boss. He gives a } \\
\text { directive to his subordinate in the office. The assignment that } \\
\text { necessitated the directive is urgent. } \\
\text { Strategy: expression of willingness } \\
\text { Style: The directee's predicate is an existential supposition; it } \\
\text { implies that good memos are not easily written. } \\
\text { The Pragmatics: The director infers that the directee is } \\
\text { willing to obey the directive, but may not perform the task } \\
\text { because of time constraint. There is therefore no reason for the } \\
\text { boss to view his interlocutor's action as an act of }\end{array}$ \\
\hline
\end{tabular}




\begin{tabular}{|c|c|}
\hline & insubordination. \\
\hline 2. Remain here until the guests leave. & $\begin{array}{l}\text { I do not pray to be pressed within this hour. } \\
\text { Situational Context: The director (a boss) instructs his } \\
\text { interlocutor not to leave an on-going public function because it } \\
\text { is the duty of this interlocutor to take proper care of the } \\
\text { speaker's luggage as he goes out to receive a phone call. } \\
\text { Strategy: excuse } \\
\text { Style: The directee mentions an envisaged emergent context } \\
\text { which justifies disobeying the directive. } \\
\text { The Pragmatics: The directee is absolutely willing to obey the } \\
\text { directive, but may not, for a reason that the speaker } \\
\text { understands and accepts; the speaker puts himself in his } \\
\text { interlocutor's situation and has no reason to misinterpret the } \\
\text { response. }\end{array}$ \\
\hline 3. All contestants should wear the tags. & $\begin{array}{l}\text { You'll see mine if the hooks are good. } \\
\text { Situational Context: The Coach of a debate competition } \\
\text { directs his contestants to abide by the regulations of the } \\
\text { competition by wearing their tags. } \\
\text { Strategy: excuse; self-defense; explanation } \\
\text { Style: The speaker uses a conditional clause to make a } \\
\text { commissive (promise). } \\
\text { The Pragmatics: The decoder's reply counts as compliance } \\
\text { because the decoder presupposes that the hooks are good. The } \\
\text { expression You'll see mine strongly implies implicit obedience } \\
\text { because seeing the tag is only possible if it is worn. }\end{array}$ \\
\hline 4. Do not sit now. & $\begin{array}{l}\text { My legs will betray me. } \\
\text { Situational Context: The director, a teacher, orders his } \\
\text { students to remain standing during a class. } \\
\text { Strategy: reason; explanation } \\
\text { Style: The directee uses a futuristic clause to imply the } \\
\text { certainty of non-compliance. } \\
\text { The Pragmatics: The speaker infers that since he lacks } \\
\text { knowledge of his interlocutor's reason for not relying on the } \\
\text { ability of his legs to keep him standing (shared knowledge), } \\
\text { this interlocutor's utterance should be believed. If this } \\
\text { interlocutor eventually sits, perlocutionary sequel is relocated - } \\
\text { the speaker's interlocutor has not offended him. }\end{array}$ \\
\hline 5. Remove your vehicle from my compound. & $\begin{array}{l}\text { Please, can I have your mechanic's phone number? } \\
\text { Situational Context: } \\
\text { A driver's car developed a problem and he had to park it in } \\
\text { front of the nearest compound. Suddenly, the landlord appears } \\
\text { and encods the above directive. } \\
\text { Strategy: topic shift; alternative; dissuading } \\
\text { Style: The offerer's interlocutor uses a pathetic topic shift that } \\
\text { is germane to the emergent situation. } \\
\text { The Pragmatics: The landlord's emotion and sense of reason } \\
\text { are evoked by the refusal strategy; the driver presupposes that } \\
\text { the landlord is not aware that the vehicle broke down, and } \\
\text { cannot insist that the vehicle be removed from the compound, } \\
\text { particularly when his interlocutor engages him in the effort to } \\
\text { find a solution to the problem. The fact that anyone can be in } \\
\text { such a position prevents the landlord from agitating further. }\end{array}$ \\
\hline 6. Seek my permission before leaving. & $\begin{array}{l}\text { You said I always did so unless I could not reach you. } \\
\text { Situational Context: A boss gives a directive to his } \\
\text { subordinate at a work place after a report reached the boss that } \\
\text { at times, this subordinate (Secretary) goes home before actual } \\
\text { closing time. } \\
\text { Strategy: expression of willingness; self-defense } \\
\text { Style: The hearer reminds the speaker of his trust and belief. } \\
\text { The Pragmatics: The emergent context is not yet speaker- } \\
\text { hearer experience. If the offeree were aware that the report } \\
\text { reached his boss, his response would probably have been } \\
\text { different. Naturally, people feel empowered when their } \\
\text { atrocities are not yet public knowledge. }\end{array}$ \\
\hline
\end{tabular}


Table(1) below ranks the refusal strategies articulated by the participants:

Table(1): Ranking of Refusal Strategies

\begin{tabular}{|l|c|c|}
\hline Strategy & Frequency & Percentage \\
\hline Reason & 5 & $19 \%$ \\
\hline Excuse & 5 & $19 \%$ \\
\hline Explanation & 5 & $19 \%$ \\
\hline Willingness & 3 & $12 \%$ \\
\hline self-defense & 4 & $15 \%$ \\
\hline Dissuading & 2 & $8 \%$ \\
\hline topic shift & 1 & $4 \%$ \\
\hline Alternative & 1 & $4 \%$ \\
\hline
\end{tabular}

\section{Results, Discussion and Conclusion}

The analysis done in this study reveals that the concept style is crucial in the performance of any speech act of refusing. Fakuade Gbenga (1998, p. 13) submits that "the word style, etymologically is derived from a Latin word "stylus" which means a pointed object. As time went on, it was known as a pointed object for writing and later as a manner of writing." Halliday (1971, pp. 332 and 334) establishes three functions of language:

" 1 . The ideational function conveys the contents of a text;

2. The interpersonal function comprises two levels of expressing the individual: the interactional and the personal level. It is concerned with the personal contribution of the speaker to the act of communication and with the speaker's attitude and options and her/his relation to the context." The characters in the drama texts analyzed in this study demonstrate the functions that language is engaged to perform in human communication. Indeed, the formal properties of language are deployed in discourse to perform social and personal needs.

Pragmatics is crucial to the literature of refusal strategy because speech act, which is the core of pragmatics, is the main instrumentality for refusing offers, directives, suggestions, invitations, etc. In the data analyzed in this study, it is clear that the socio-cultural norms of the operative language, English, do not significantly direct the use of speech act of refusing.

Different strategies abound for refusing not only offers and directives, but other speech acts. The strategies include: regret, excuse, reason, expression of willingness, explanation, adjuncts, alternatives, principles, rules, alerts, degree adverbs, educating, criticizing, self-defense, Yes... but, fake agreement/promise, expressing the gratitude, dissuading interlocutors, etc. Thus, the few strategies discovered in this study are products of the limited scope of the investigation. Hinging on the Projection Principle which justifies using selected samples to make generic, logical conclusions about research phenomena, the frequency of each strategy - as evident in table 1 above: reason $(19 \%)$, explanation $(19 \%)$, excuse (19\%) willingness $(12 \%)$, self-defense (15\%), topic shift (4\%), among others - can be used to state that in the drama genre, the common refusal strategy in any context of situation is giving excuse, explanation and reason; these strategies establish the rationale for refusing and also prevents confrontation. The choice of the drama genre for a research of this kind is significant. Drama is a representation of life. Through characterization, themes and plot a lot about everyday human interaction is presented through drama.

The analysis shows that in a given communication situation, multiple refusal strategies can be used to refuse an offer or a directive. I contend at this juncture, that it takes speech act fusion for refusals to be incredibly potent in any context of situation. This is important to the participants who are primarily interested in politeness when they refuse an offer, a directive, a suggestion, an invitation, etc. 


\section{Limitations of the Study}

The twelve corpora (Offers 1-6 and Directives 1-6) appear insufficient for a research of this kind that investigates refusal strategies in the drama genre and human communication in general. This limitation is significant given the fact that the more the selected corpora (data), the more the situational contexts, and this can enhance the readers' understanding of the stylistic and pragmatic underpinnings in the speech act of refusing in various communications.

\section{8. $\quad$ Suggestions for Further Studies}

The following suggestions are important:

- There should be more research on the teaching of the normative properties of English in ESL contexts;

- More research on cross-cultural and universal features of the speech act of refusal will enrich the literature. Such research will significantly be supportive to the works of Beebe et al., (1990, pp. 72-73) and Liao (1994).

\section{References:}

[1] Al-Kahtani. S. A. W., Refusals Realizations in Three Different Cultures: A Speech Act Theoreticallybased Cross-cultural Study, Journal of King Saudi University, 18(2005), 35-57.

[2] Austin. J. L., How to Do Things with Words, Cambridge, Harvard University Press, (1962).

[3] Beebe. L., Takahashi. T., \& Uliss-Weltz. R., Pragmatic Transfer in ESL Refusal. In Scarcella, E. Anderson and S. Krashen (Eds.) 55-73. Cambridge: M.A., (1990).

[4] Bach. K. Harnish. R., Linguistic Communication and Speech Acts. Cambridge, Massachusetts: The MIT Press, (1979)

[5] Brown. P. \& Levinson. S., Politeness: Some Universals in Language Use, Cambridge: Cambridge University Press, (1987).

[6] Fakuade. G., Studies in Stylistics and Discourse Analysis, Yola: Paraclete Publishers, (1998).

[7] Fairclour. N., Language and Power, USA: Longman, (1996).

[8] Ghazanfari. M., Bonyadi. A., \& Malekzadeh. S., Investigating Cross-linguistic Differences in Refusal Speech Act among Native Persian and English Speakers, International Journal of Research Studies in Language Learning, 2(3)(2013), 49-63, https://doi.org/10.5861/ijrsll.2012.214

[9] Grice. H. P., Logic and Conversation. In Cole and Morgan (Eds.) (1975).

[10] Halliday. M. A. K., Linguistic Function and Literary Style: A Symposium. In S. Chatman (Ed.) 330-365. London and New York: Oxford University Press, (1971).

[11] Hassani. R., Mardani. M., \& Dastjerdi. H. V., A Comparative Study of Refusals: Gender Distinction and Social Status in Focus, The International Journal-Language Society and Culture, 32(2011).

[12] Lawal. A., Stylistics in Theory and Practice. Ilorin: (ALSG), University of Ilorin, (1999).

[13] Leech. G. \& Michael. S., Style in Fiction. London and New York: Longman, (1981). 
[14] Liao. C., A Study on the Strategies Maxim, and Development of Refusal in Mandarin Chinese, China: Taipei, (1994).

[15] Mey. J., An Introduction to Pragmatics, Oxford: Blackwell Publishing, (2001).

[16] Searle. J., Speech Acts: An Essay in the Philosophy of Language, New York: Cambridge University Press, (1969).

[17] Xin. L. \& Jieqiong. S., A Pragmatic Study on Refusal Strategies by Chinese College, Cambridge Journal of China Studies, 10(2)(2018), 67-82. 